\title{
Exchange between a river and groundwater, assessed with hydrochemical data
}

\author{
E. Hoehn ${ }^{1}$ and A. Scholtis ${ }^{2}$ \\ ${ }^{1}$ Eawag, Swiss Federal Institute for Water Science and Technology, 8600 Dübendorf, Switzerland \\ ${ }^{2}$ Cantonal Office for the Environment Thurgau, 8510 Frauenfeld, Switzerland
}

Received: 2 November 2010 - Published in Hydrol. Earth Syst. Sci. Discuss.: 26 November 2010

Revised: 2 March 2011 - Accepted: 9 March 2011 - Published: 21 March 2011

\begin{abstract}
We describe the chemical composition of groundwater from an alluvial granular aquifer in a valley fill flood plain (River Thur Valley). The river flows along this valley and is mostly downwelling on its way, indirectly through an unsaturated zone in the upstream part, and directly through the water-saturated bed in the downstream part. River Thur has been channelized with barriers for more than a century. In 1992, the authorities started to restore a section of River Thur with riverbed enlargements. The land use in the flood plain and the seasonal and climatic conditions (e.g., hot dry summer 2003) result in alterations of the natural geochemical composition of the river water. This groundwater is partly to mainly recharged by bank filtration. Several wells exist near the river that draw groundwater for drinking. In some of these wells, the groundwater has a very short residence time in the subsurface of days to weeks. Bed enlargements and other operations for an enhancement of the exchange of water between the river and groundwater increase the contamination risk of the nearby wells. During bank filtration, the groundwater changes gradually its composition, with increasing distance from the river and with depth in the aquifer. From today's changes of the water quality during riverbank filtration, we tried to extrapolate to the groundwater quality that may arise from future river restorations. Today the groundwater body consists of a mixture of groundwater from the seepage of precipitation and from riverbank filtration. The main difference between river water and groundwater results from the microbial activity in riverbed and bank materials. This activity leads to a consumption of $\mathrm{O}_{2}$ and to a higher partial pressure of $\mathrm{CO}_{2}$ in the groundwater. Criteria
\end{abstract}

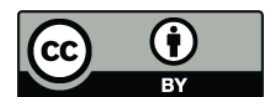

Correspondence to: E. Hoehn (hoehn@eawag.ch) for the distinction of different groundwater compositions are the distance of a well from the river and the subsurface residence time of the groundwater to reach this well.

\section{Introduction}

Many alpine and perialpine flood plains are accompanied by rivers. Past developments of these rivers resulted in widespread channelization for both flood protection and hydropower generation. These developments have altered the flow regime, the structure and the ecological function of the rivers (Peter, 2010). They resulted in a decrease of the dynamics in the river corridors, which has widely been recognized in recent years. River restoration has become a priority element for future flood protection. Among the hydrogeomorphological restoration options, enlarging the riverbed has shown to be an efficient way to improve the ecological state of a riverine landscape (e.g., Baumann, 2003). Artificial barriers reduced the longitudinal connectivity between the river and the flood plain. The subsurface of flood plains consists of coarse-grained alluvial outwash material. These unconsolidated sediments make the main aquifers of these regions. The rivers of the flood plains exchange intensively with the groundwater along river corridors, e.g., by bank filtration. They have the potential to improve the connectivity between the river and the groundwater.

Alluvial groundwater is a resource for drinking water. Riverbed enlargements in flood plains can conflict with groundwater abstraction, in that the fraction of bank filtration groundwater increases in a well and the subsurface residence time of the pumped water decreases. The extent of bank filtration varies with the discharge rate of the rivers

Published by Copernicus Publications on behalf of the European Geosciences Union. 

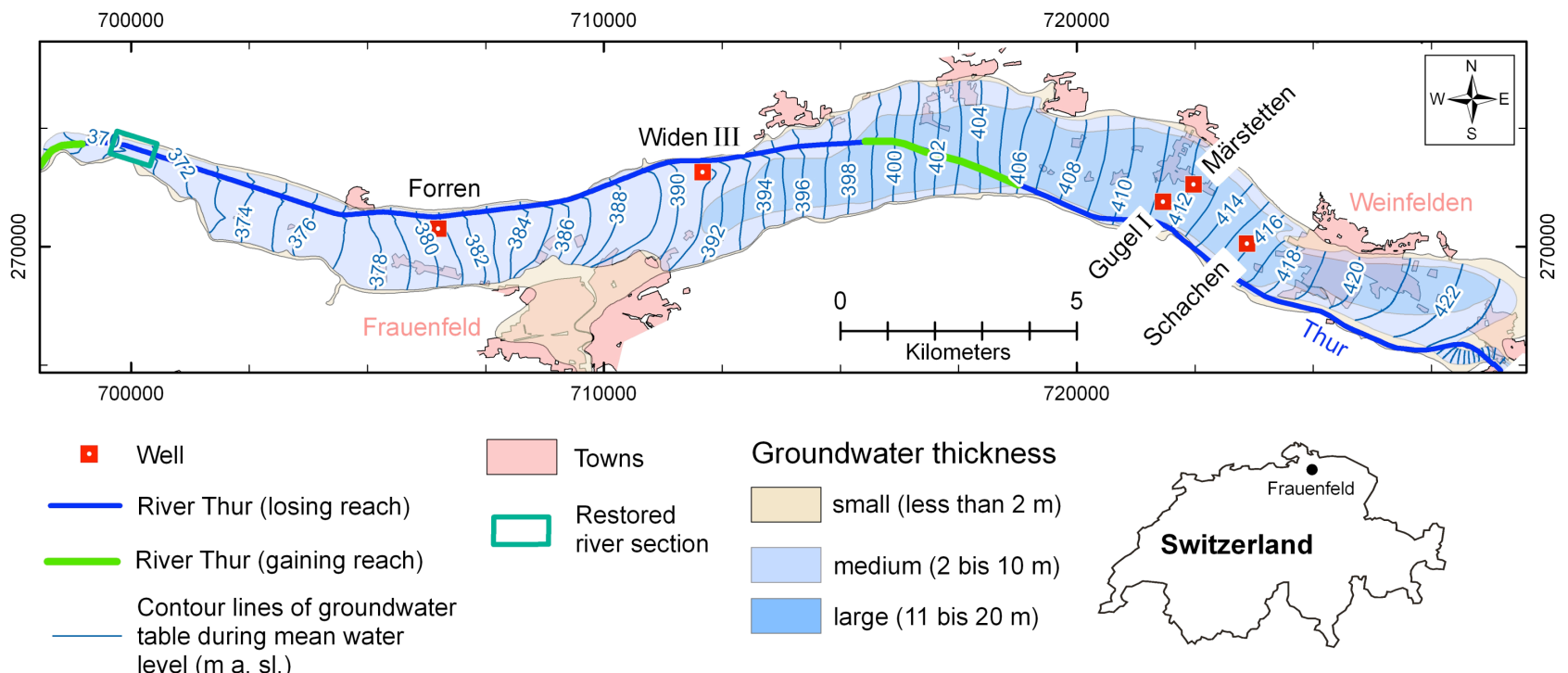

Fig. 1. Map view of groundwater in River Thur valley aquifer, Switzerland. Axes of Swiss Federal Coordinate system. Blue and grey areas, groundwater thickness (dark blue, $11-20 \mathrm{~m}$, light blue, $2-10 \mathrm{~m}$, grey, $<2 \mathrm{~m}$ ). Pink areas, towns. Green quadrangle, restored river section. Red quadrangles, wells quoted in text. Thick blue lines, River Thur (blue, losing reach, green, gaining reach). Thin blue lines, mean groundwater isopotential lines (m a.s.1.). (Map reproduced with permission of Cantonal Office of Geoinformatics Thurgau, 29 October 2008; modified from Vogt et al., 2009.)

and is enhanced during floods. Floods lead to a dilution of geogenic solutes and to accidental peak anthropogenic contaminations (Hoehn et al., 2007). The rivers receive water from wastewater treatment plant (WWTP) outlets. Elaborate restoration attempts are underway to return human-impacted river channels to more natural conditions and more dynamics, especially in the context of flood protection (see Woolsey et al., 2007 and references herein). Groundwater that is used for drinking-water purposes must satisfy legal quality requirements. The law requires minimal residence times of the groundwater in the subsurface to reach a drinking-water well. Many wells are located close to the riverbanks and draw groundwater, which is very young and contains a high fraction of young bank-filtrate.

Successful river restoration requires careful consideration of, among other things, the impact on groundwater in the river corridor. These operations can result in gradual changes of the groundwater composition. They could lead to an increasing fraction of young bank-filtration water and thus to a reduction of the residence time of the pumped groundwater, to an extent that self-decontamination and the mixing of young and older groundwater are no longer sufficient to guarantee high-quality drinking water in the wells (Hoehn and Meylan, 2009). Unclogging of formerly clogged riverbeds increases the exchange of water (at least for a certain period). Therefore, a good knowledge of the groundwater quality of bank filtration systems is crucial for successful restoration operations (e.g. McKnight and Bencala, 1989; Lautz and Fanelli, 2008; Zobrist, 2010). The aim of this work is to discuss the chemical processes that lead to these concentrations changes today, and the effects on the groundwater quality that future river restorations can have. This is of importance, when the groundwater is used for drinking water. For this discussion, we chose as a test region the flood plain in the River Thur valley, Northern Switzerland (Fig. 1).

\section{Groundwater types in the river-recharged alluvial aquifer of the River Thur valley}

The flood plain of the River Thur valley consists of an alluvial gravel and sand aquifer. The groundwater of this valley and the water of River Thur have been described extensively (e.g., Hoehn et al., 2007; Cirpka et al., 2007; Vogt et al., 2009; Zobrist, 2010). The river has been channelized with barriers for more than a century. In 1992, the authorities started to restore an experimental section of the River Thur along a reach of about one km (see Fig. 1). Other sections should follow soon. The alluvial groundwater of the River Thur flood plain is used for drinking water by about 20 public wells. For a description of the hydrochemical properties of the groundwater resource, the authorities of the Cantonal Office for the Environment Thurgau have access to an extensive data set (early analyses since 1969, most values since 1990). We relied on about 100 sampling stations in the Thurtal flood plain (mostly complete wells for drinking water, incomplete wells for irrigation, and short-diameter observation wells most of these wells fully screened), and on about 2000 analyses. The water samples were analyzed according to the 


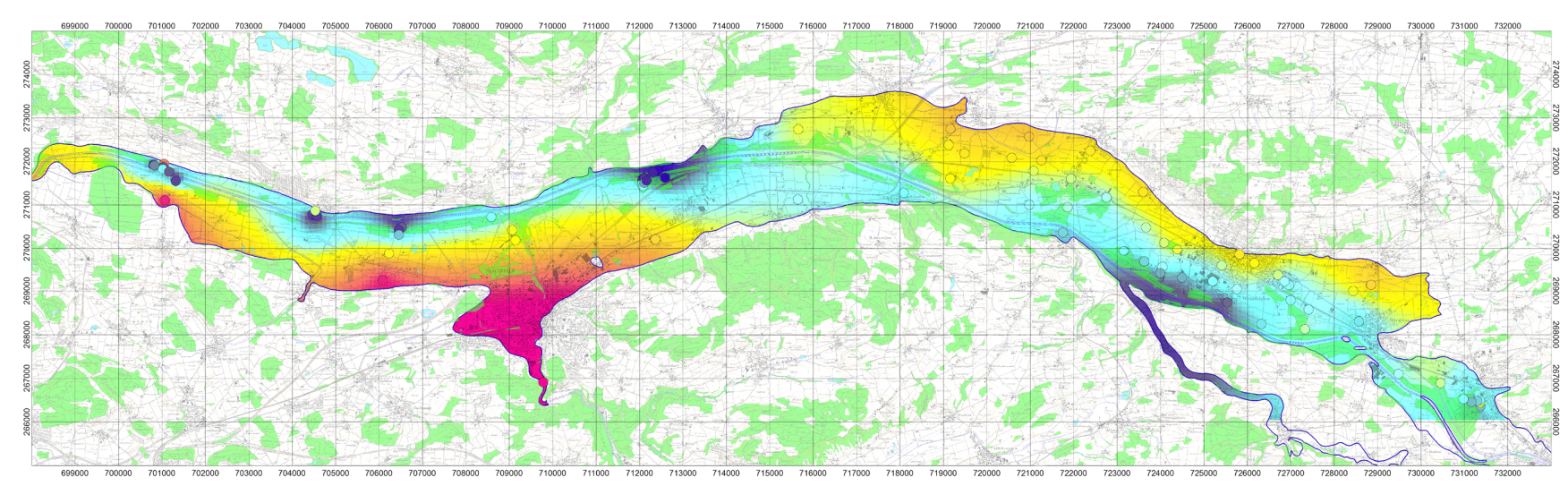

Fig. 2. Plan view representation of alkalinity in the groundwater of River Thur valley, using CHEMMAP. Yellow, orange, and red hues, high alkalinity ( $>350 \mathrm{mg} \mathrm{L}^{-1} ; 61 \mathrm{mg} \mathrm{HCO}_{3}^{-} \mathrm{L}^{-1}=1 \mathrm{mmol} \mathrm{L}^{-1}$ ), light and dark blue hues, low alkalinity $\left(<350 \mathrm{mg} \mathrm{L}^{-1}\right.$ ). $1 \mathrm{mmol} \mathrm{L}^{-1}=61 \mathrm{mg} \mathrm{L}^{-1}$. Colored domain: Alluvial groundwater, thickness $>2 \mathrm{~m}$. North is up; General groundwater flow direction from East to West.

methods given in the Swiss Handbook for Foodstuff (FOPH, 2003: Schweizerisches Lebensmittelbuch, SLB), chap. 27A.

Table 1 summarizes average values of the chemical water analyses. Most waters can be classified as of calcium carbonate origin (type $\mathrm{Ca}-\mathrm{Mg}-\mathrm{HCO}_{3}-\left(\mathrm{NO}_{3}\right)$, classification scheme of Jäckli, 1970), which is typical for most perialpine regions. At $\mathrm{pH}$ values of 7.1-7.7, calcium $\left(\mathrm{Ca}^{2+}\right)$ and alkalinity (hydrogen carbonate, $\mathrm{HCO}_{3}^{-}$) make up for more than $50 \%$ of the total mineralization of $200-400 \mathrm{mg} \mathrm{L}^{-1}$. We underpin with maps the dependence of the groundwater quality on the distance from River Thur. These maps are drawn with software, which is based on a kriging algorithm coupled with a GIS (Cantonal Office for the Environment Thurgau, 2002). This program transforms point data to maps. As examples, we discuss in Fig. 2 the areal distribution of alkalinity, and in Fig. 3 that of dissolved oxygen. These maps average over the whole aquifer depth and use average concentrations from various analyses. Given a lower alkalinity in River Thur than in the groundwater, the hues in Fig. 2 quantify the mixing of downwelling water from the river with groundwater not of bank-filtration origin. Blue hues in Fig. 2 (low alkalinity) represent high fractions of bank filtration near River Thur. Yellow to red hues (high alkalinity) represent low fraction of bank filtration at greater distances from the river. Other main ionic constituents such as $\mathrm{Ca}$ or $\mathrm{SO}_{4}$ and $\mathrm{EC}$ show an areal distribution, which is similar to that of alkalinity. If the fraction groundwater of bank filtration origin changes during a restoration operation, alkalinity would change, too.

Figure 3 shows a general trend from high concentrations in dissolved oxygen at the upstream end of the flood plain in the East to lower concentrations at the downstream end in the West. Blue hues in Fig. 3 (high oxygen concentrations) represent bank filtration through an unsaturated zone in the upper part of the flood plain (indirect bank filtration). The unsaturated zone is aerated, and not much oxygen is lost during
Table 1. Average concentrations of chemical water constituents in water of River Thur, in alluvial groundwater of wells located at distances of $>300 \mathrm{~m}$ and $<300 \mathrm{~m}$ from the banks of River Thur, and in groundwater from valley slopes, and numbers of respective sampling stations.

\begin{tabular}{|c|c|c|c|c|c|}
\hline & & $\begin{array}{l}\text { River } \\
\text { Thur }\end{array}$ & $\begin{array}{c}\text { groundwater, } \\
<300 \mathrm{~m} \\
\text { distance } \\
\text { to } \\
\text { River } \\
\text { Thur }\end{array}$ & $\begin{array}{c}\text { groundwater, } \\
>300 \mathrm{~m} \\
\text { distance } \\
\text { to } \\
\text { River } \\
\text { Thur }\end{array}$ & $\begin{array}{c}\text { groundwater } \\
\text { from } \\
\text { valley } \\
\text { slopes }\end{array}$ \\
\hline \multicolumn{2}{|c|}{ Number of sampling stations } & 26 & 30 & 50 & 17 \\
\hline & units & & & & \\
\hline $\begin{array}{l}\text { water } \\
\text { temperature }\end{array}$ & ${ }^{\circ} \mathrm{C}$ & 10.2 & 11.1 & 11.1 & 11.1 \\
\hline pH (field) & $\mathrm{pH}$ & 8.4 & 7.5 & 7.2 & 7.3 \\
\hline $\begin{array}{l}\text { electric } \\
\text { conductivity } \\
25^{\circ} \mathrm{C}\end{array}$ & $\mu \mathrm{S} \mathrm{cm}^{-1}$ & 449 & 500 & 641 & 723 \\
\hline $\mathrm{O}_{2}$ & $\mathrm{mg} \mathrm{L}^{-1}$ & 11.5 & 3.6 & 5.9 & 8.2 \\
\hline $\mathrm{O}_{2}$ Sat. & $\%$ & 108 & 41 & 58 & 62 \\
\hline DOC & $\mathrm{mg} \mathrm{L}^{-1}$ & 3.2 & 1.5 & 1.0 & 0.8 \\
\hline $\mathrm{Ca}^{2+}$ & $\mathrm{mg} \mathrm{L}^{-1}$ & 69 & 77 & 101 & 112 \\
\hline $\mathrm{Mg}^{2+}$ & $\mathrm{mg} \mathrm{L}^{-1}$ & 12 & 14 & 18 & 28 \\
\hline $\mathrm{Na}^{+}$ & $\mathrm{mg} \mathrm{L}^{-1}$ & 10 & 10 & 9 & 5 \\
\hline $\mathrm{K}^{+}$ & $\mathrm{mg} \mathrm{L}^{-1}$ & 2.4 & 2.8 & 2.5 & 1.4 \\
\hline $\mathrm{Cl}^{-}$ & $\mathrm{mg} \mathrm{L}^{-1}$ & 13 & 13 & 14 & 13 \\
\hline $\mathrm{SO}_{4}^{2-}$ & $\mathrm{mg} \mathrm{L}^{-1}$ & 11 & 12 & 15 & 29 \\
\hline $\mathrm{NO}_{3}^{-}$ & $\mathrm{mg} \mathrm{L}^{-1}$ & 10 & 11 & 18 & 24 \\
\hline alkalinity & $\mathrm{mmol} \mathrm{L}^{-1}$ & 4.1 & 4.7 & 5.9 & 6.9 \\
\hline total hardness & $\mathrm{mmol} \mathrm{L}^{-1}$ & 2.2 & 2.5 & 3.7 & 4.0 \\
\hline TDS & $\mathrm{mg} \mathrm{L}^{-1}$ & 240 & 271 & 334 & 387 \\
\hline
\end{tabular}

bank filtration. Yellow to red hues in Fig. 3 (low oxygen concentrations) represent bank filtration through a saturated zone in the lower part of the flood plain (direct bank filtration). River Thur has a high organic load from WWTP outlets (see river water concentrations in DOC, in Table 1). During 


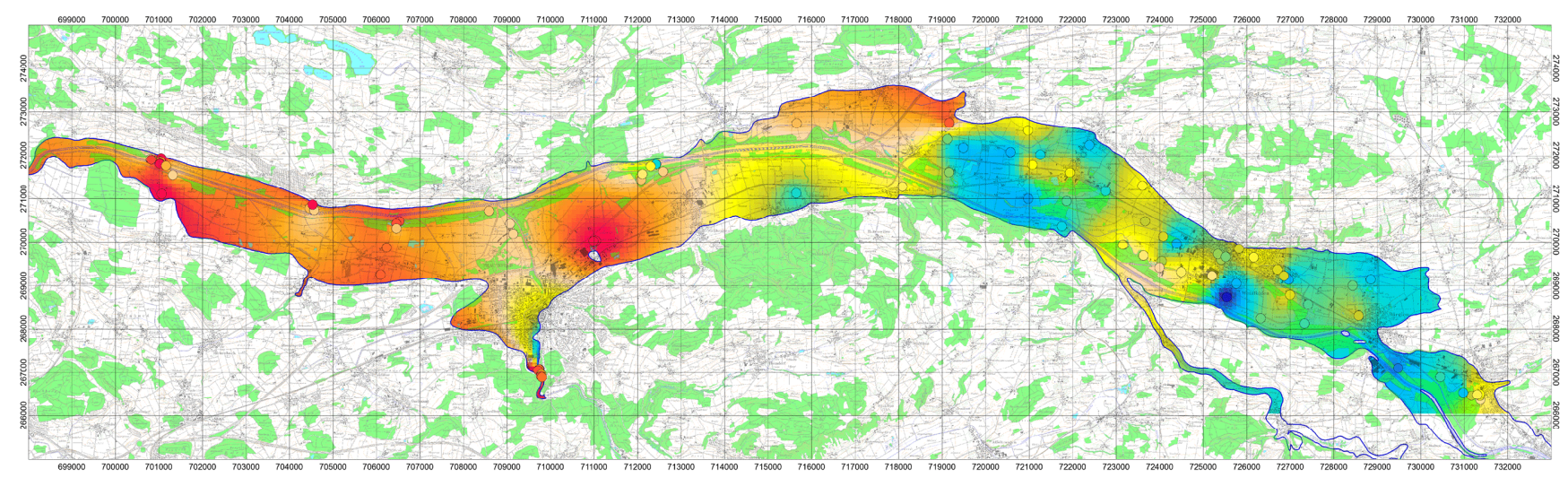

Fig. 3. Plan view representation of oxygen concentrations in the groundwater of River Thur valley, using CHEMMAP. Yellow, orange, and red hues, low concentrations $\left(<5 \mathrm{mg} \mathrm{L}^{-1}\right)$, light and dark blue hues, high concentrations $\left(>5 \mathrm{mg} \mathrm{L}^{-1}\right)$. Colored domain: alluvial groundwater, thickness $>2 \mathrm{~m}$. North is up; General groundwater flow direction from East to West.

saturated bank filtration of river water of a high organic load, dissolved oxygen $\left(\mathrm{O}_{2}\right)$ is consumed significantly by bacteria in the riverbed material. This is explained by increasing biogeochemical oxygen consumption in the riverbed. Especially in the summer months with river-water temperatures above $20^{\circ} \mathrm{C}$, the young groundwater of bank-filtration origin can become suboxic, in spite of the good aeration of the water in River Thur. If the temperature of an enlarged river rises in summer, the oxygen consumption during bank filtration could rise as well.

The summer 2003 was very hot and dry in Central Europe. The temperatures of River Thur were such that oxygen was totally consumed in one of the wells near the river ("Forren" Well; see Fig. 1). Reducing conditions in the anoxic groundwater resulted in a dissolution of natural iron and manganese oxides/hydroxides from the aquifer material. A sustainable groundwater protection scheme requires a good resource quality, rather than water treatment (Hoehn and Meylan, 2009).

In Table 1, we describe separately the groundwater composition of different water types by the main water constituents. With the data, we postulate that the alluvial groundwater near the river consists of a mixture of water from River Thur and groundwater at an arbitrary distance from the river of $>300 \mathrm{~m}$. Using Darcy's Law, we assume from assessments of aquifer hydraulic conductivity $\left(400-500 \mathrm{~m} \mathrm{~d}^{-1}\right)$, hydraulic gradient (about 0.005 ), and effective porosity (estimated to be at about 0.15; Diem et al., 2010) that the distance of $300 \mathrm{~m}$ corresponds to groundwater residence times of about $20 \mathrm{~d}$, hence about double the time required for groundwater protection zone, S2. Table 1 shows that the concentrations of the main water constituents $(\mathrm{Ca}, \mathrm{Mg}$, alkalinity, $\mathrm{SO}_{4}$ ) as well as the specific electric conductivity (EC) have a trend in the groundwater with increasing distance from the river.

\subsection{Water from River Thur}

Water from River Thur is mineralized, with EC values of $300-500 \mu \mathrm{S} \mathrm{cm}^{-1}$ and alkalinity values of $2-3 \mathrm{mmol} \mathrm{L}^{-1}$ $\left(1 \mathrm{mmol} \mathrm{L}^{-1}=61 \mathrm{mg} \mathrm{L}^{-1}\right)$. As surface water, it is saturated in oxygen and its $\mathrm{pH}$ is in the $\mathrm{CO}_{2} / \mathrm{CaCO}_{3}$ equilibrium of the atmosphere (compare with Zobrist, 2010).

\subsection{Groundwater $>\mathbf{3 0 0} \mathrm{m}$}

Groundwater at distances of $>300 \mathrm{~m}$ from the banks of River Thur corresponds to $>20 \mathrm{~d}$ subsurface residence times of $>20 \mathrm{~d}$. This groundwater is more mineralized than the river water. The concentrations in geogenic compounds $(\mathrm{Ca}, \mathrm{Mg}$, $\left.\mathrm{HCO}_{3}\right)$ are higher in the groundwater than in the river. Dissolved organic carbon (DOC) from WWTPs, and from agricultural and industrial activities is of lower concentration in the groundwater than in the river. Especially, the nitrate concentrations are higher, which indicates an influence of agricultural activities. The oxygen concentrations are lower than those of the river. We postulate from the groundwater composition and from isotope tracer investigations that this groundwater originates to a major fraction from the seepage of precipitations and to a minor fraction from riverbank filtration (Hoehn et al., 2007).

\subsection{Groundwater $<\mathbf{3 0 0} \mathrm{m}$}

Groundwater at distances from the banks of River Thur of $<300$ m corresponds to subsurface residence times of $<20 \mathrm{~d}$. Concentration values for EC and alkalinity lie between those of the river and those of groundwater at distances from the banks of $>300 \mathrm{~m}$. We conclude from this that most wells located at distances from the river of $<300 \mathrm{~m}$ exhibit high and variable fractions of young groundwater of riverbank origin. The seasonal temperature amplitude of the groundwater in these wells is between that of the river and almost zero in 
the far field of the river, which corroborates the mixing assumption from water chemistry (Vogt et al., 2009). These parameters can be used to quantify the fraction groundwater of bank-filtration origin in wells near rivers. We attribute the increasing concentration of the groundwater in geogenic compounds with distance to the river to its increasing reaction time for mineral dissolution in the subsurface. Isotopic investigations corroborate the finding of increasing groundwater residence times with increasing flow distance from the river (Hoehn et al., 2007).

\subsection{Groundwater from valley slopes, recharged by precipitation}

Groundwater from the valley slopes is recharged exclusively by precipitation. The slopes of the River Thur valley consist mainly of tertiary sandstones and marls. Springs emerge from the sandstones, at the slopes of the River Thur valley. Furthermore, this groundwater is discharged in the subsurface to the alluvial aquifer of the valley. The groundwater from valley slopes influences the composition of the groundwater in the alluvial aquifer. It is more mineralized than the alluvial groundwater, and it contains more dissolved carbonates (Table 1). The nitrate concentrations are also higher, which indicates an impact of agricultural activities.

\section{Depth dependence of groundwater quality}

Fluid logging with a continuously logging multi-parameter probe (temperature, EC, $\mathrm{O}_{2}$, and $\mathrm{pH}$; YSI 600, YSI Inc., Yellow Springs, OH 45387, USA) allowed in some wells to identify changes in the groundwater composition with depth (e.g., "Schachen" Well, see Fig. 1). Lower values of EC, higher concentrations in $\mathrm{O}_{2}$ and higher temperature in the upper part of the saturated aquifer than in the lower part suggested a vertical stratification of the groundwater. From these results, we established a conceptual model of the spatial distribution of the various groundwater types. Groundwater of young bank-filtration origin $(<300 \mathrm{~m}$ distance from the river, and $<20 \mathrm{~d}$ residence time) reveals a composition that is in many ways similar to that of river water (Fig. 4). At distances from a river of $>300 \mathrm{~m}$ and at residence times of $>20 \mathrm{~d}$, the fractions of young water from bank-filtration origin are so low that the groundwater is difficult to be distinguished from what originated entirely from the seepage of precipitation. The shift in composition is continuous from one groundwater type to the other, and, as mentioned above, the boundary of $300 \mathrm{~m}$ used in Table 1 is arbitrary. Groundwater of precipitation origin is mostly older than that of riverbank origin. In this hydrogeological situation, alluvial groundwater is often stratified, with layers of young and older groundwater of bank-filtration origin on top (blue and green in Fig. 4, respectively), and old groundwater of precipitation origin at the bottom (pink in Fig. 4).

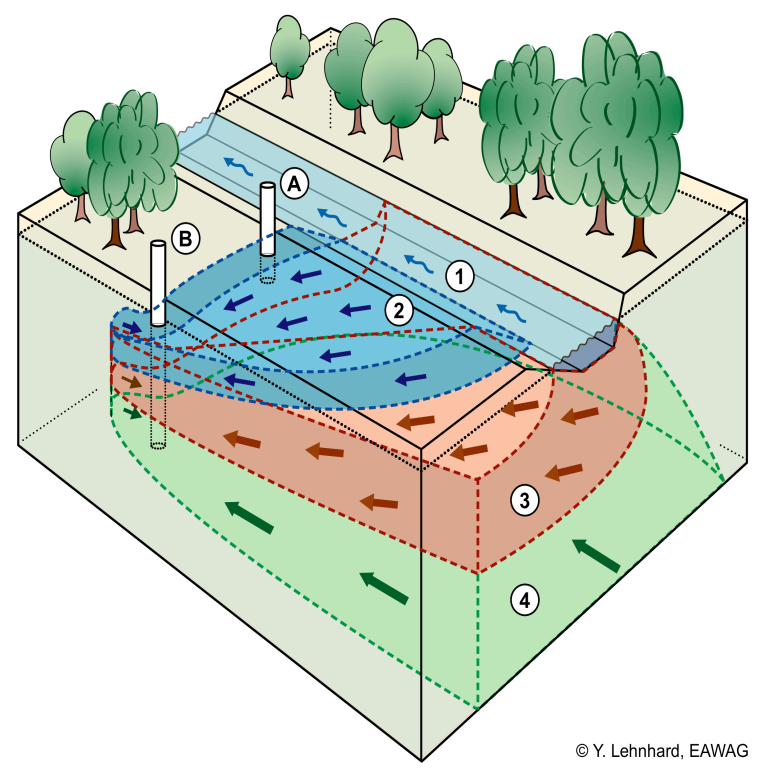

Fig. 4. Schematic block diagram showing relationship between a river, losing water through a saturated bed, and groundwater: (1) River (light blue), (2, 3) Groundwater of river-bank filtration origin (dark blue, $<300 \mathrm{~m}$ flow distance from river, and $<20 \mathrm{~d}$ residence time; pink, $>300 \mathrm{~m}$ flow distance from river, and $>20 \mathrm{~d}$ residence time), (4) groundwater not of bank-filtration origin (green).

\section{Implications for river restoration}

One of the goals of river restoration is to improve the connectivity between rivers and adjacent groundwater. The results of our hydrochemical investigation showed an intensive interaction between the alluvial groundwater and River Thur. Many alpine and perialpine rivers have similar patterns of up- and downwelling like River Thur. Most of these rivers are accompanied by high-yield drinking-water wells that have contributing areas pointing in the direction of the river. Unclogging of the riverbed during river enlargements and subsequent re-clogging can lead to spatial and temporal changes in the composition of the young groundwater of bank-filtration origin, due to a reduction of groundwater residence times, combined with an increase of its fractional mixing contribution. We conclude from our study that depending on the quality of the river water, drinking-water wells near rivers can suffer from groundwater contamination following river restoration operations. Elevated fractions of bank-filtration water and reduced subsurface residence times during or after enlargements, or other artificial unclogging of riverbeds, pose the risk of deteriorating the groundwater quality. This risk is difficult to predict and quantify. Accumulation of trace contaminants from wastewaters or oxygen reduction due to high water temperatures can lead to a deterioration of drinking-water wells.

The Swiss Federal Ordonnance on Water Protection (Gewässerschutzverordnung, 1998, GSchV) forbids 
river-bed enlargements in groundwater protection zones S2 of drinking-water wells, i.e., with a subsurface residence time of the groundwater in the saturated aquifer to reach a well of at least 10 days. Our investigations give valuable information for water districts, to react with appropriate measures. They help to secure a sustainable groundwater quality during and after restoration operations. Such measures could include, e.g., more intense quality control of the well water, temporary closure of the well, admixture of water from a different source, or water treatment.

Acknowledgements. We thank Donald Kaden (kadenpartner ag, Frauenfeld, Switzerland) for the design and the implementation of the CHEMMAP computer model. We acknowledge with thanks the redrawing of Fig. 1 from Fig. 2 of Vogt et al. (2009) and an internal review of the manuscript, by Tobias Vogt. Thanks to the two unknown reviewers for their good suggestions.

Edited by: E. Durisch-Kaiser

\section{References}

Baumann, M.: Hochwasserschutz, Flussraumaufwertung und Grundwasserschutz im Thurtal - Vorgehen zur Lösung von Konflikten: Bull. Angew. Geol., 8(2), 47-55, 2003.

Cantonal Office for the Environment Thurgau: CHEMMAP, Projektbeschreibung für ein Programm zur Umwandlung von PunktMessdaten in Flächenkarten, Interner Bericht, Amt für Umwelt Kanton Thurgau, unveröff., Project description for a computer program to transform point data to maps - Internal Report, Cantonal Office for the Environment Thurgau, unpublished, 2002.

Cirpka, O. A., Fienen, M. N., Hofer, M., Hoehn, E., Tessarini, A., Kipfer, R., and Kitanidis, P. K.: Analyzing bank filtration by deconvoluting time series of electric conductivity, Groundwater, 45(3), 318-328, doi:10.1111/j.1745-6584.2006.00293.x, 2007.

Diem, S., Vogt, T., and Hoehn, E.: Räumliche Charakterisierung der hydraulischen Leitfähigkeit in alluvialen SchotterGrundwasserleitern: ein Methodenvergleich, Grundwasser, 15(4), 241-251, 2010.
FOPH: Swiss Handbook of Foodstuff, Schweiz, Lebensmittelbuch, SLB, Federal Office for Public Health, BAG, Bundesamt für Gesundheit, chap. 27A, Drinking Water, http: //www.fr.ch/lcc/files/pdf9/richtlinien_wasser_slmb.pdf (last access: 18 March 2011), 2003.

Hoehn, E. and Meylan, B.: Maßnahmen zum Schutz flussnaher Trinkwasserfassungen bei wasserbaulichen Eingriffen in Fliessgewässer voralpiner Schotterebenen, Measures to protect drinking-water wells near rivers of perialpine flood plains, in German, Grundwasser, 14(4), 255-263, doi:10.1007/s00767009-0111-3, 2009.

Hoehn, E., Cirpka, O. A., Hofer, M., Zobrist, J., Kipfer, R., Baumann, M., Scholtis, A., and Favero, R.: Untersuchungsmethoden der Flussinfiltration, Investigation methods for river bank filtration, in German, Gas-Wasser-Abwasser, 8(7), 497-505, 2007.

Jäckli, H.: Klassifikation von Grundwasservorkommen, Groundwater classification, in German, Eclog. Geol. Helv., 63(2), 389-434, 1970

Lautz, L. K. and Fanelli, R. M.: Seasonal biogeochemical hotspots in the streambed around restoration structures, Biogeochemistry, 91(1), 85-104, 2008.

McKnight, D. and Bencala, K. E.: Reactive iron transport in an acidic mountain stream in Summit County, Colorado, A hydrologic perspective, Geochim. Cosmochim. Acta, 53, 2225-2234, 1989.

Peter, A.: A plea for the restoration of Alpine rivers: Basic principles derived from the "Rhone-Thur" Case Study, in: Alpine Waters, edited by: Bundi, U., Hdb. Env. Chem., 6, Springer, Berlin, Heidelberg, 247-260, 2010.

Vogt, T., Hoehn, E., Schneider, Ph., and Cirpka, O. A.: Untersuchung der Flusswasserinfiltration in voralpinen Schottern mittels Zeitreihenanalyse, Riverbank filtration investigation in perialpine alluvial aquifer using time series analyses, in German, Grundwasser, 14(3), 179-194, doi:10.1007/s00767-009-0108-y, 2009.

Woolsey, S., Capelli, F., Gonser, T., Hoehn, E., Hostmann, M., Junker, B., Paetzold, A., Roulier, Ch., Schweizer, St., Tiegs, S. D., Tockner, K., Weber, h., and Peter, A.: A strategy to assess river restoration success, Freshwater Biol., 52, 752-769, 2007.

Zobrist, J.: Water chemistry of Swiss Alpine rivers, in: Alpine Waters, edited by: Bundi, U., Hdb. Env. Chem., 6, Springer, Berlin, Heidelberg, 95-118, 2010. 